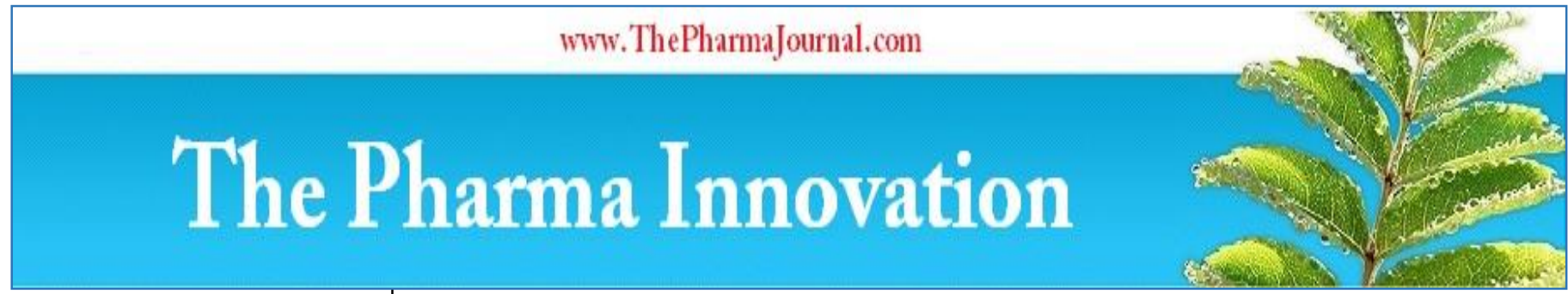

ISSN (E): 2277 - 7695

ISSN (P): 2349-8242

NAAS Rating: 5.23

TPI 2021; 10(4): 239-244

(C) $2021 \mathrm{TPI}$

www.thepharmajournal.com

Received: 09-01-2021

Accepted: 21-02-2021

Chungkham Chanu Malemnganbi Student, M.Sc., Department of Community Science in Food

Science and Nutrition, College of Community Science, CAU, Tura, Meghalaya, India

\section{Namita Singh}

Associate Professor, Department of Food Science and Nutrition, College of Community Science, CAU, Tura, Meghalaya, India

\section{Corresponding Author:} Namita Singh

Associate Professor, Department of Food Science and Nutrition, College of Community Science, CAU, Tura, Meghalaya, India

\section{Standardization of different products by using different level of Moringa leaves powder and its acceptability}

\author{
Chungkham Chanu Malemnganbi and Namita Singh
}

DOI: $\underline{\text { https://doi.org/10.22271/tpi.2021.v10.i4d.5933 }}$

\begin{abstract}
Moringa oleifera is one of the most popular species among the Moringaceae family. Moringa oleifera is a fast growing tree grown throughout tropics and sub - tropics and all over world; it is a drought tolerant, multipurpose and one of most valuable tree found on earth due to its medicinal and nutritional properties. The study was an attempt to standardize the different products by using different levels of moringa leaves powder and to study the acceptability of the products. Since, Moringa oleifera leaves contained considerable amount of essential micro nutrients. Moringa leaves powder were standardized and incorporated in popularly consumed food products like cake, chapatti, and bhatura and aloo bhujia and it was compared with that of the standard. Finding revealed that addition of moringa powder leaves in cake at three different levels with 20,30, and 50 per cent respectively. Among these three different levels along with control the cake with 20 per cent of moringa leaves powder was most accepted by the sensory panel. The incorporation of moringa leaves powder in chapatti at three different levels with 5,10 and 15 per cent respectively. The well accepted by the sensory panel was chapatti with 5 per cent moringa leaves powder. In bhatura and aloo bhujia the incorporation was done only in single levels at 5 percent and was well accepted as compared to the control. Hence, moringa leaves is a nutrient dense and easily available food resource that has the ability to improve the micro nutrients quality.
\end{abstract}

Keywords: Acceptability, dehydration, moringa oleifera, sensory evaluation

\section{Introduction}

Moringa oleifera is generally known as 'horseradish tree' or 'drumstick tree' or 'cabbage tree' or 'miracle tree' (Koul and Chase, 2015) ${ }^{[11]}$. Moringa oleifera is native to India but it is widely distributed in Ethiopia, Pacific islands, Florida, Sudan Caribbean, Philippines, South Africa, Asia, and Latin America (Fahey 2005) ${ }^{[3]}$. In India Moringa, oleifera is known as 'drumstick tree' or 'horseradish tree'. There are 13 identified species of Moringa. Moringa oleifera is one of the most popular species among the Moringaceae family. Moringa oleifera is a fast growing tree grown throughout tropics and sub - tropics and all over world; it is a drought tolerant, multipurpose and one of most valuable tree found on earth due to its medicinal and nutritional properties (Mekonnen 2006) ${ }^{[3]}$. It is commonly known as 'sahajan' in Hindi, 'sajna' in Garo and 'Drumstick tree' or 'Horseradish tree' in English (Mishra et al., 2011) ${ }^{[14]}$. Rural household use Moringa leaves could serve as a less expensive way of promoting their nutritional status because the leaves could be dried cheaply with solar dryer and stored (Glover et al., 2016) ${ }^{[4]}$. The whole plant is edible from leaves to roots (Bolarinwa et al., 2019) ${ }^{[1]}$. Moringa tree is used as a spice (mainly roots), cooking and cosmetic oil (seed) and as a medicinal plant (all plant organs), (Rebecca, et al., 2006) ${ }^{[20]}$. Moringa leaves are also known as store house of nutrients (Kasolo et al., 2010) ${ }^{[8]}$. Fresh leaves of Moringa are used as vegetable in cookery, soup, salads, fried foods, curd etc. (Yameoga et al., 2011) ${ }^{[26]}$. The dried powder is completely eatable and is used in soups and a variety of traditional foods (Srinivasamurthy et al. 2017) ${ }^{[24]}$. Nowadays, nutritionalists are trying to encourage cultivation and incorporation of GLVs in different recipes with minimum effort and little cost, giving a great benefit. The recipes containing GLVs would not only bring variety to the diet and also helps in fighting Vitamin A deficiency along with other micronutrient deficiency (Joshi and Mehta, 2010) ${ }^{[5]}$. Dry Moringa leaves could be sprinkled on any food items to improved nutritional value. (Clement et al., 2017) ${ }^{[2]}$. Moringa oleifera contain phytosterol compound and the leaves have certain quality as lactagogum i.e. increasing breast milk production (Kiranawati and Nurjanah, 2014) ${ }^{[9]}$. Moringa leaves posses fibre, fat, protein and mineral like Magnesium, Calcium, Phosphorus, Iron, Copper and Sulfur. 
Vitamin like vitamin A (carotene), vitamin B (choline), vitamin B1 (thiamine), riboflavin, nicotinic acid and ascorbic acid are present. Different amino acid like His, Arg, Trp, Lys, Thr, Phe, Leu, Ile, Met, Vel are found in Moringa leaves (Rockwood et al., 2013; Mbikay 2012) [21, 12]. A several numbers of reports on the nutritional qualities of Moringa now exist in both the scientific and the popular literature. It is frequently said that moringa leaves contain more vitamin $\mathrm{A}$ than carrots, more calcium than milk, more vitamin $\mathrm{C}$ than the oranges, more iron than spinach, more potassium than bananas and the protein quality of moringa leaves is comparable to that of milk and eggs (Joshi and Mehta, 2010) ${ }^{[5]}$. The one of the most vital component of Moringa Oleifera leaves is Quercetin, which is used as inhibitor for the growth of cancer cell in human beings (Satwase et al., 2013) ${ }^{[22]}$. Traditional medicine techniques used Moringa leaves to treat different diseases which mainly include gastrointestinal problems, headache, inflammation, anemia, fever, eye infection, bronchitis, poor nutrition, inner ear infection, skin infection (Clement et al., 2017) ${ }^{[2]}$. Moringa leaves provides a vigorous mixture of direct and indirect antioxidants that can explain its various health promoting effects (Tumer et al., 2005) ${ }^{[25]}$. Moringa oil has been used as a cosmetic items such as body and hair care as a moisturizer and skin conditioner (Mishra et al., 2012) ${ }^{[15]}$. The leaves also carried out various pharmacological activities in our system, such as analgesic, antihypertensive, antitumor activity, and anti - inflammatory effects (Prabhu et al., 2011) ${ }^{[19]}$.

\section{Materials and Methods}

\section{Preparation of Moringa leaves powder (MLP)}

The fresh leaves of Moringa Oleifera were collected from Tura West Garo Hills, Meghalaya and powder was developed in the Food and Nutrition Lab of Department of foods and Nutrition, College of Community Science, Tura, Meghalaya. Fresh, undamaged moringa leaves were sorted and washed with clean water thoroughly to eliminate all dirt. Then water were drained and spread out on a stainless steel mesh racks and leaves were dried for some time. The washed and air dried leaves were then dried in a tray drier at the temperature of $60^{\circ} \mathrm{C}$ for 4 hours. Thereafter, well-dried leaves were powdered using a grinder with stainless steel blade to get Moringa leaves powder. In order to retain color, texture \& nutrient techniques of dehydration were standardized.

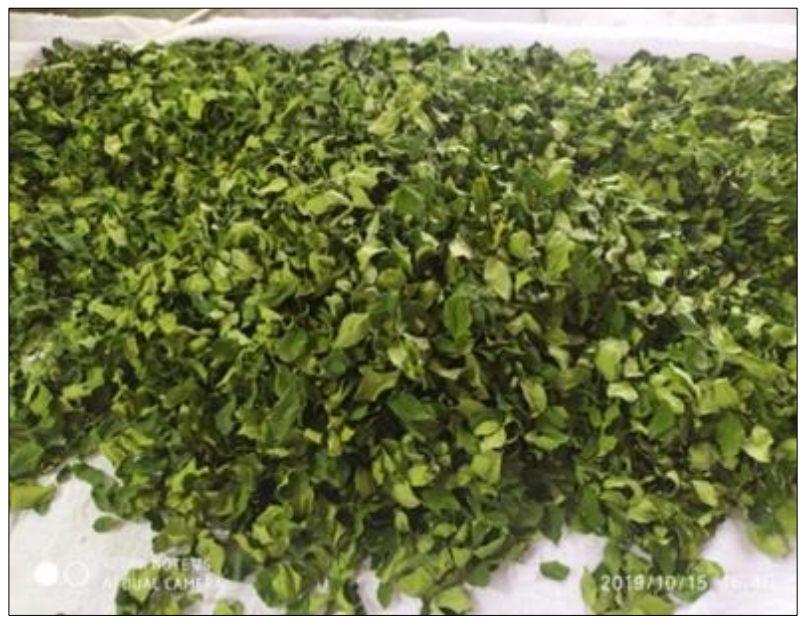

Plate 1: Dried moringa leaves

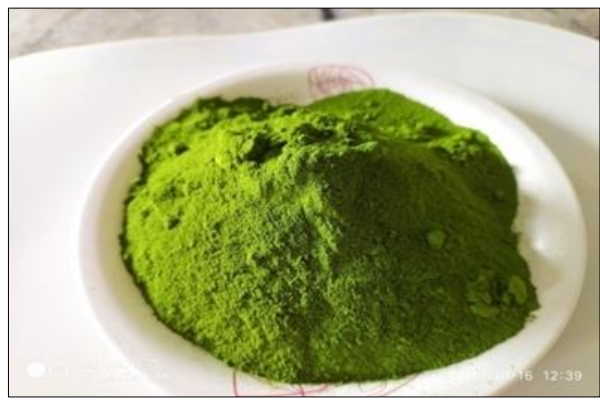

Plate 2: Moringa leaves powder

\section{Product development}

Moringa leaves powders (MLP) at different level were incorporated in different product. The incorporation level of moringa leaves powder were taken on the basis of various preliminary trials conducted to determine the suitability of different percents of MLP for the product development. The developed products namely cake, bhatura, chapatti and aloo bhujia were selected to be enhanced with different percent of MLP. Bhatura and aloo bhujia were incorporated with $5 \%$ of MLP. Chapatti was incorporate with $5 \%, 10 \%$ and $15 \%$ of MLP. Cake was incorporated with 20\%, 30\% and 50\% MLP. The product detailed has been presented in table (1).

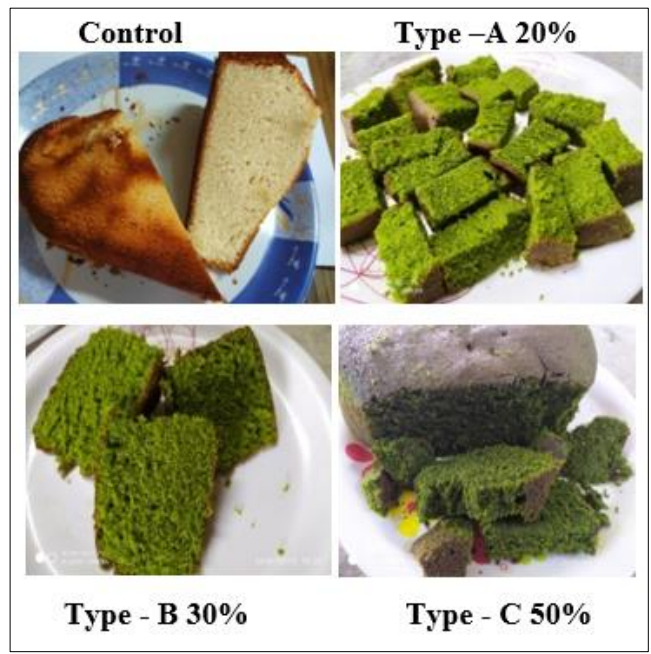

Plate 3: Cake incorporated MLP

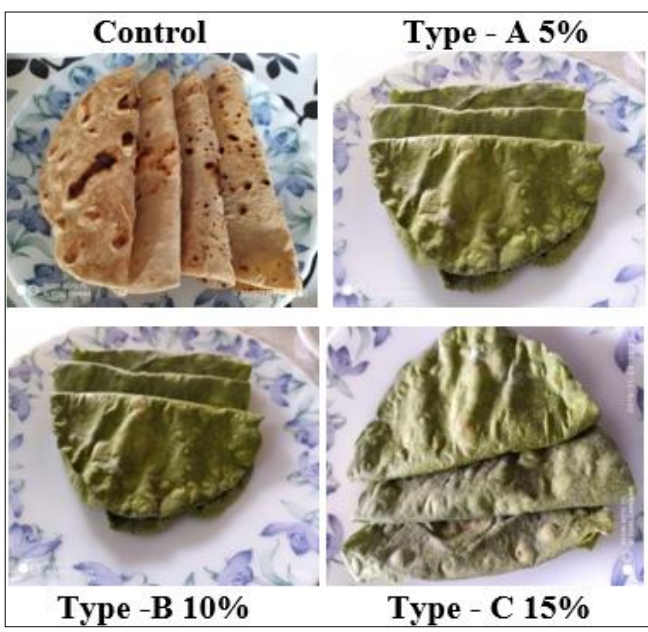

Plate 4: Chapatti incorporated MLP 


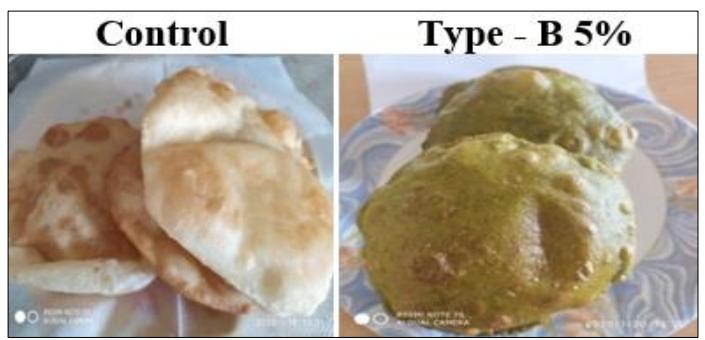

Plate 5: Bhatura incorporated MLP

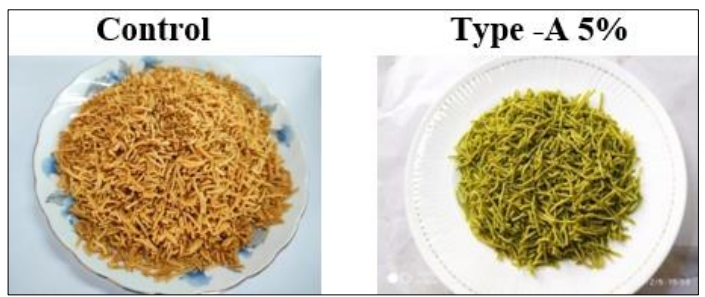

Plate 6: Aloo bhujia incorporated MLP

\section{Sensory evaluation}

The sensory evaluation of the developed products were performed by evaluating five major sensory characteristics such as appearance, texture, taste, aroma and overall acceptability using a 9 point hedonic score card where 9 indicated "like extremely" and 1 indicated "dislike extremely" by a panel of $30 \mathrm{semi}$ - trained panelists i.e. teachers from the Department of Food and Nutrition, final year students of Food Science and Nutrition \& Nutrition and Dietetics of college of Community Science, Tura Meghalaya.

\section{Statistical analysis}

The obtained observation data from various parameters were recorded and statistically analyzed. Mean and standard deviation for the various parameters were computed.

\section{Results and Discussion}

Cake, chapatti, bhatura and aloo bhujia were formulated by incorporating moringa leaves powder at different level and the mean score for organoleptic acceptability are shown in table 2.

\section{Sensory evaluation and overall acceptability}

Cake was formulated with incorporating moringa leaves powder at different levels such as Type-A 20\%, Type-B 30\% and Type-C $50 \%$ of MLP and wheat flour chapatti was used as a control. The mean score of the control cake were 6.2, 7.2, 7.8, 7.0and 7.2 for appearance, texture, taste, aroma and overall acceptability respectively which fells in the category of 'like moderately'. In Type-A 20\% cake the scores for appearance, texture, taste; aroma and overall acceptability were 7.9, 7.6, 7.7, 7.5 and 7.6, respectively. However, the lowest acceptability was found at Type - C 50\% substitution with MLP in cake. In Type - C 50\% cake mean scores for appearance, texture, taste, aroma and overall acceptability were 4.7,4.8,4.6,4.7 and 4.8 respectively and fell in the category of 'dislike slightly'. Among these different level of MLP cake, cake with $20 \%$ of dried moringa leaves powder had higher score in all parameters than its other different concentration. The incorporation of MLP products was light green in color with a bland flavor. It gave light green colour to the food at lower levels (5 and 10 percent) which increased to darker shades of green at the $15 \mathrm{~g}$ and $20 \mathrm{~g}$ level per serving in most of the product (Joshi and Verma,2017). Cereals grains are deficient in two essential amino acids, lysine and tryptophan. And wheat is not an exception in this; therefore incorporation of Moringa will be a best complement and hence producing a better nutritional quality cake. These agree with previous study on Moringa and cakes. (Olushola, 2006) ${ }^{[18]}$. It can be seen that out of the four concentrations along with control, Type -A 20\% of MLP cake was most preferred by the sensory panelist as per the mean scores. Other product the chapatti was prepared by incorporating Moringa leaves powder at various acceptable levels such as Type A 5\%, Type -B 10\% and Type- C 15\% respectively to the wheat chapatti (control). The result showed that the control chapatti was 'like moderately' in terms of appearance (7.0), texture (6.4), taste (6.8), aroma (7) and overall acceptability (7). The mean score of the sensory characteristic of Type - A 5\% chapatti were 7.7,7.2,7.4,7.4 and 7.3 respectively. In Type -B 10\% chapatti the mean score of appearance, texture, taste and overall acceptability were 7.2,6.8,6.3,6.2 and 6.8. In Type -C 15\% chapatti the mean score for sensory acceptability were 6.4,5.7,5.8,5.2 and 6.The sample containing Type- A 5\% of moringa leaves powder gave the highest mean score as compare to the other concentration and most accepted by the panel member. Study done by Singh and Grover (2014) [23] showed chapatti and poori incorporated with Bengal gram leaves were accepted to a level of $10 \%$ of incorporation. In present study Bhatura was prepared by incorporating Type-A 5\% MLP to the refine flour bhatura (control). The result showed that. The mean scores of sensory characteristic of the control were appearance (7.4), texture (6.6), taste (7.6), aroma (7.2) and overall acceptability (7.3). In Bhatura the appearance score had lower in (6.9) Type - A 5\% of moringa leaves powder bhatura than control. Except appearance rest of the parameters had significantly higher score in Type - A 5\% of MLP bhatura than control and it was most preferred by sensory panelist. The sensory score of aloo bhujia prepared without the use of MLP (control) were 7.6, 6.8, 7.7, 7.6 and 7.8 for appearance, texture, taste aroma and overall acceptability respectively. The scores for sensory characteristics like appearance, texture, taste, aroma and overall acceptability of aloo bhujia prepared from Type - A 5\% MLP were 7.4,7.5,7.8,7.6 and 7.9 respectively and showed that they fell in the category of ' like moderately'. The result observed that control and Type-A 5\% aloo bhujia had slight difference in all the parameters. The highest mean score given to the Type $-\mathrm{A} 5 \%$ aloo bhujia based on the sensory panelist. However, there was not much difference in overall acceptability of control and MLP bhujia (7.8\&7.9) respectively. In aloo bhujia and Bhatura, deep frying method was employed whereas chapatti was roasted on the non stick pan and cake were baked in OTG oven. The levels of MLP incorporation to the products were acceptable at $20 \%$, but beyond 20 percent level of incorporation the scores gradually decreased. Numerous research reports have shown the different uses of Moringa Oleifera leaves in making food products such as cake by Kolawole et al., $2013^{[10]}$, cookies by Mounimah (2015), muffin by Shrinivasamurthy et al., (2017), and amla (Karim et al., 2015) ${ }^{[7]}$. Fig 1: present the pictorial graph of the sensory evaluation of chapatti. From this graph, the appearance of the Type-A 5\% chapatti gave the best appearance than the others concentration. In fig: 2 present the sensory evaluation graph of Bhatura. Here the overall acceptability of the Bhatura was more in the Type - A 5\%. In fig: 3 the taste of Type $-\mathrm{A} 5 \%$ aloo bhujia scored the highest taste than the control aloo bhujia. From fig: 4 it is observed that Type - A $20 \%$ cake had the highest scored in taste and the lowest taste score was in Type - C 50\% cake. 
Table 1: Standardized recipes for incorporated Moringa leaves powder of cake, chapatti, Bhatura and Aloo bhujia

\begin{tabular}{|c|c|c|c|c|c|c|c|c|c|c|c|}
\hline Recipe & \multirow{2}{*}{$\begin{array}{c}\text { Level of } \\
\text { incorporation }\end{array}$} & \multicolumn{10}{|c|}{ Ingredients(g) } \\
\hline \multirow{5}{*}{ Cake } & & $\begin{array}{l}\text { Wheat } \\
\text { flour }\end{array}$ & MLP & Powdered sugar & Butter & Egg & \multicolumn{2}{|c|}{ Baking powder } & \multicolumn{3}{|c|}{ Vanilla } \\
\hline & Control & 100 & - & 100 & 100 & 3 & \multicolumn{2}{|r|}{1 tsp } & \multicolumn{3}{|c|}{ Few drops } \\
\hline & Type - A 20\% & 80 & 20 & 100 & 100 & 3 & \multicolumn{2}{|r|}{1 tsp } & \multicolumn{3}{|c|}{ Few drops } \\
\hline & Type - B 30\% & 70 & 30 & 100 & 100 & 3 & \multicolumn{2}{|r|}{1 tsp } & \multicolumn{3}{|c|}{ Few drops } \\
\hline & Type - C 50\% & 50 & 50 & 100 & 100 & 3 & \multicolumn{2}{|c|}{1 tsp } & \multicolumn{3}{|c|}{ Few drops } \\
\hline \multirow{5}{*}{ Chapatti } & & \multicolumn{3}{|c|}{ Whole wheat flour } & \multicolumn{7}{|c|}{ Moringa leaves powder (MLP) } \\
\hline & Control & \multicolumn{3}{|c|}{100} & \multicolumn{7}{|c|}{-} \\
\hline & Type-A 5\% & \multicolumn{3}{|c|}{95} & \multicolumn{7}{|c|}{5} \\
\hline & Type-B $10 \%$ & \multicolumn{3}{|c|}{90} & \multicolumn{7}{|c|}{10} \\
\hline & Type - C $15 \%$ & \multicolumn{3}{|r|}{85} & \multicolumn{7}{|c|}{15} \\
\hline \multirow{3}{*}{ Bhatura } & \multirow{3}{*}{$\begin{array}{c}\text { Control } \\
\text { Type -A 5\% }\end{array}$} & $\begin{array}{l}\text { Wheat } \\
\text { flour }\end{array}$ & MLP & $\begin{array}{c}\text { Whole wheat } \\
\text { flour }\end{array}$ & Suji & Curd & $\begin{array}{l}\text { Baking } \\
\text { powder }\end{array}$ & $\begin{array}{c}\text { Soda } \\
\text { bicarbonate } \\
\end{array}$ & \multicolumn{2}{|c|}{ Sugar } & $\begin{array}{l}\text { Oil (for } \\
\text { frying) }\end{array}$ \\
\hline & & 100 & - & - & - & 30 & 1.25 & A pinch & 2.5 & & 47.5 \\
\hline & & 60 & 5 & 20 & 15 & 30 & 1.25 & A pinch & 2.5 & & 47.5 \\
\hline \multirow{3}{*}{$\begin{array}{l}\text { Aloo } \\
\text { bhujia }\end{array}$} & \multirow{3}{*}{$\begin{array}{c}\text { Contro } 1 \\
\text { Type -A 5\% }\end{array}$} & $\begin{array}{l}\text { Gram } \\
\text { flour }\end{array}$ & MLP & Potatoes & \multicolumn{2}{|c|}{ Chat masala/mint powder } & Asafoetida & \multicolumn{2}{|c|}{$\begin{array}{c}\text { Garam masala } \\
\text { powder/ } \\
\text { Red chilli powder }\end{array}$} & & $\begin{array}{l}\text { Oil } \\
\text { r frying) }\end{array}$ \\
\hline & & 100 & - & 90 & \multicolumn{2}{|c|}{ Sprinkle } & 0.5 & \begin{tabular}{|c|}
0.6 \\
\end{tabular} & & & 100 \\
\hline & & 95 & 5 & 90 & \multicolumn{2}{|c|}{ Sprinkle } & 0.5 & 0.6 & & & 100 \\
\hline
\end{tabular}

MLP - Moringa Leaves Powder

*Salt - as required for the taste

Table 2: Sensory evaluation of the developed product

\begin{tabular}{|c|c|c|c|c|c|}
\hline Product & Appearance & Texture & Taste & Aroma & Overall acceptability \\
\hline \multicolumn{6}{|c|}{ Cake } \\
\hline Control & $6.2 \pm 0.45$ & $7.2 \pm 0.45$ & $7.8 \pm 0.35$ & $7.0 \pm 0.25$ & $7.2 \pm 0.41$ \\
\hline Type - A 20\% & $7.9 \pm 0.12$ & $7.6 \pm 0.50$ & $7.7 \pm 0.45$ & $7.5 \pm 0.51$ & $7.6 \pm 0.48$ \\
\hline Type - B $30 \%$ & $7.6 \pm 0.71$ & $7.8 \pm 0.56$ & $7.8 \pm 0.56$ & $7.3 \pm 0.56$ & $7.5 \pm 0.63$ \\
\hline Type-C 50\% & $4.7 \pm 1.2$ & $4.8 \pm 1.18$ & $4.6 \pm 1.45$ & $4.7 \pm 1.43$ & $4.8 \pm 1.56$ \\
\hline \multicolumn{6}{|c|}{ Chapatti } \\
\hline Control & $7 \pm 0.65$ & $6.4 \pm 0.63$ & $6.8 \pm 0.77$ & $7 \pm 0.45$ & $7 \pm 0.65$ \\
\hline Type - A 5\% & $7.7 \pm 0.79$ & $7.2 \pm 1.17$ & $7.4 \pm 0.63$ & $7.4 \pm 0.63$ & $7.3 \pm 0.61$ \\
\hline Type-B $10 \%$ & $7.2 \pm 0.41$ & $6.8 \pm 0.83$ & $6.3 \pm 0.89$ & $6.2 \pm 0.96$ & $6.8 \pm 0.51$ \\
\hline Type-C $15 \%$ & $6.4 \pm 0.50$ & $5.7 \pm 0.96$ & $5.8 \pm 0.91$ & $5.2 \pm 0.96$ & $6 \pm 0.53$ \\
\hline \multicolumn{6}{|c|}{ Bhatura } \\
\hline Control & $7.4 \pm 0.50$ & $6.6 \pm 1.04$ & $7.6 \pm 0.48$ & $7.2 \pm 0.45$ & $7.3 \pm 0.48$ \\
\hline Type - A 5\% & $6.9 \pm 0.25$ & $6.6 \pm 0.63$ & $7.6 \pm 0.50$ & $7.5 \pm 0.51$ & $7.4 \pm 0.50$ \\
\hline \multicolumn{6}{|c|}{ Aloo Bhujia } \\
\hline Control & $7.6 \pm 0.89$ & $6.8 \pm 0.77$ & $7.7 \pm 0.72$ & $7.6 \pm 0.60$ & $7.8 \pm 0.72$ \\
\hline Type - A 5\% & $7.4 \pm 0.74$ & $7.5 \pm 0.51$ & $7.8 \pm 0.48$ & $7.6 \pm 0.48$ & $7.9 \pm 0.45$ \\
\hline
\end{tabular}

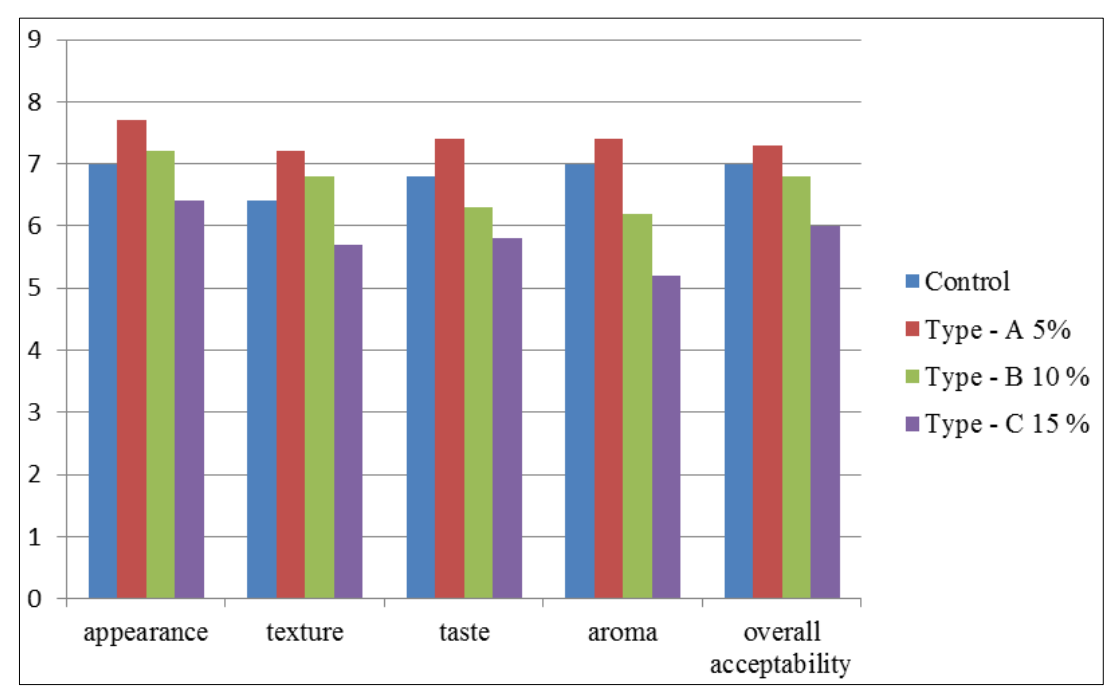

Fig 1: Sensory evaluation of chapatti 


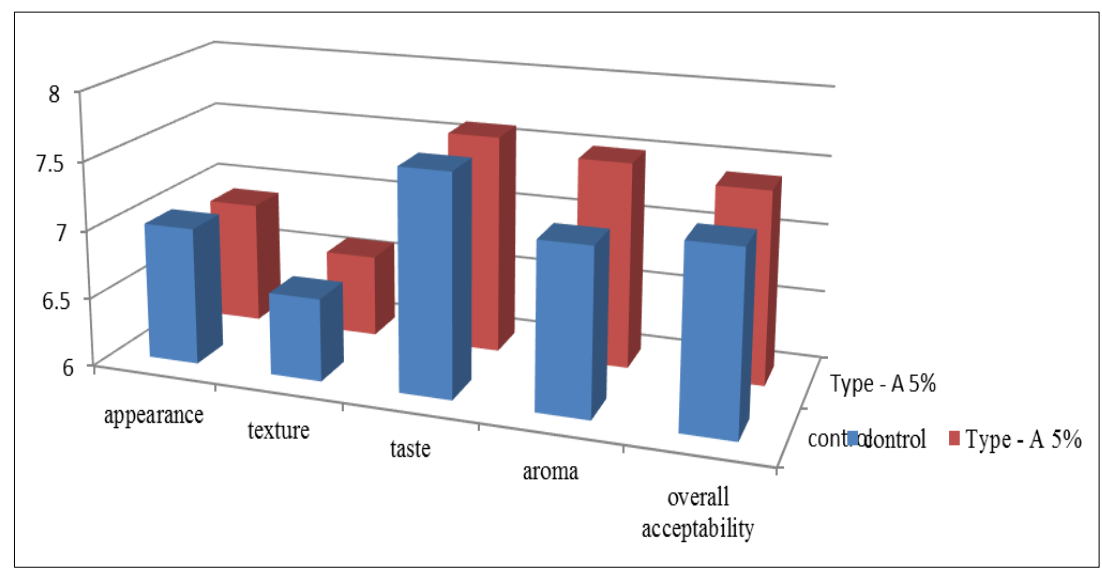

Fig 2: Sensory evaluation of bhatura

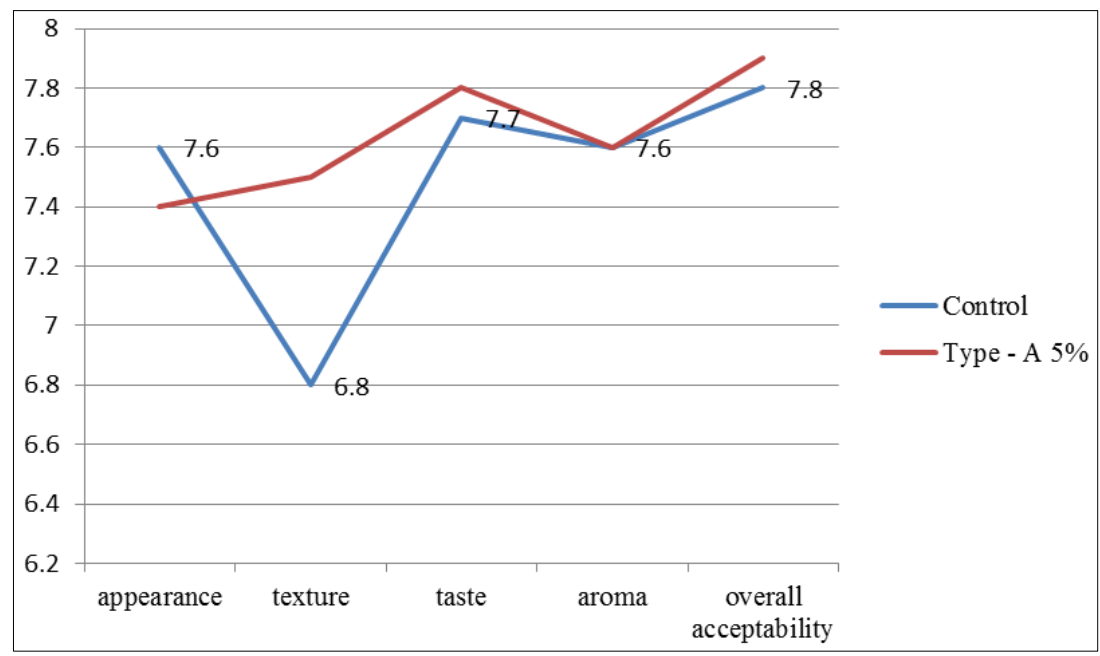

Fig 3: Sensory evaluation of Aloo bhujia

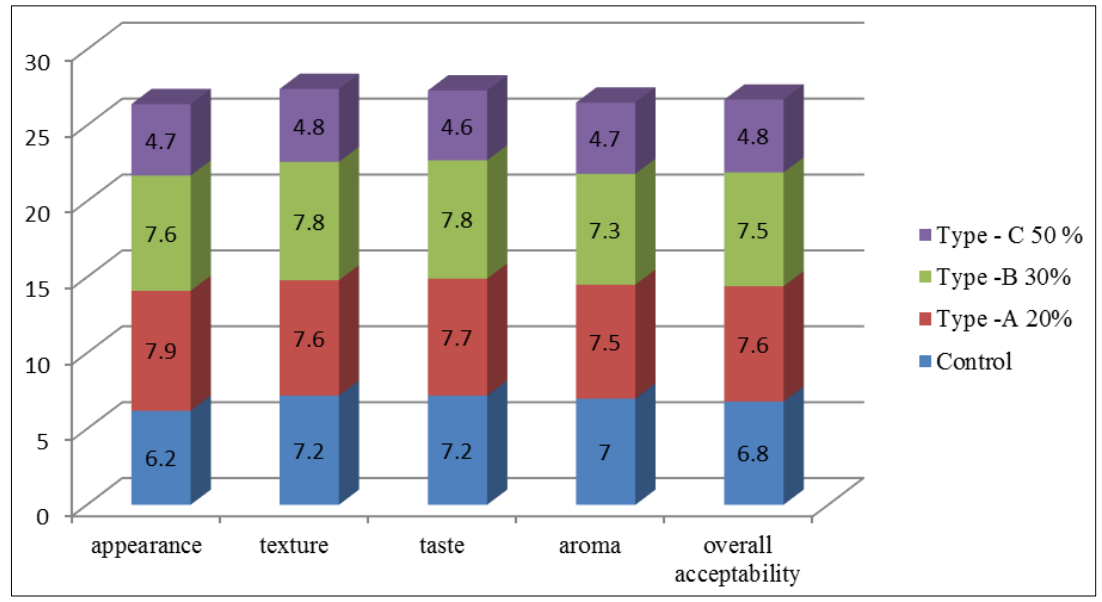

Fig 4: Sensory evaluation of cake

\section{Conclusion}

The study concluded that incorporation of MLP in different product such as cake, bhatura, aloo bhujia and chapatti at different concentration. When considering all the sensory characteristics of the four products produced by incorporating MLP. The products were acceptable at $20 \%$ level of MLP incorporation, but beyond $20 \%$ level of incorporation the scores gradually decreased. The research work was able to identify the potential of Moringa in the development of different products and this will improved the nutritional status of the consumer.

\section{References}

1. Bolarinwa IF, Aruna TE, Raji AO. Nutritive value and acceptability of bread fortified with Moringa seed powder. J Saudi Society Agric Sci 2019, 195-200.

2. Clement A, Olatunde M, Patrick O, Joyce P. Effect of Drying Temperature on Nutritional Content of Moringa Oleifera Leave. World J Food Sci Technol 2017;1(3):9396.

3. Fahey JW. Moringa oleifera: A review of the medical evidence for its nutritional, therapeutic and prophylactic properties 2005. Open access available on online at: http://www.TFLJournal.org/article.php/20051201124931 
586. Accessed 27 September 2019.

4. Glover AM, Aryeetey R, Afari E, Nyarko A. Micronutrient composition and acceptability of Moringa oleifera leaf - fortified dishes by children in Ada - East district, Ghana. Food Sci Nutr 2016;5(2):317-323.

5. Joshi P, Mehta D. Effect of dehydration on the nutritive value of drumstick leaves. J Metabolomics Syst Biol 2010;1(1):5-9.

6. Joshi P, Varma K. Preparation of Value added Products from Dehydrated Drumstick Leaves. Online International Interdisciplinary Research Journal 2017; $\{\mathrm{Bi}-$ Monthlyb $\}: 7(4)$.

7. Karim O, Kayode R, Oyeyinka S, Oyeyinkam A. Physico - chemical properties of stiff dough amla prepared from plaintain (Musa paradisca) flour and Moringa (Moringa oleifera) leaf powder. Food Health Dis 2015;4:48-58.

8. Kasolo JN, Bimennya GS, Ojok L, Ochieng J, Ogwalokeng JW. Phytochemocals and uses of Moringa oleifera leave in Ugandan rural communities. J Med Plants Res 2010;4:753-757.

9. Kiranawati TM, Nurjanah N. Improvemennt of Noodles Recipe for Increasing Breastmik: Design of the Moringa Noodles. Am J Food Sci Technol 2014;2(3):88-92.

10. Kolawole FL, Balogun MA, Opalake DO, Amali HE. An evaluation of nutritional and sensory qualities of wheat Moringa cake 2013. Open access available on online at: http://dx.doi.org/10.4314/agrosh.v13i1.9.Accessed 27 September 2019.

11. Koul B, Chase N. Moringa oleifera Lam: Panacea to several maladies. J Chem Pharm Res 2015;7:687-707.

12. Mbikay M. Therapeutic potential of Moringa oleifera leaves in chronic hyperglycemia and dyslipidemia: A review, Front. Pharmacol 2012;3:1-12.

13. Mekonnen Daba. Miracle Tree: A Review on Multipurposes of Moringa oleifera and Its Implication for Climate Change Mitigation. J Earth Sci Clim Change 2016; doi:10.4172/215-7617.1000366.

14. Mishra G, Singh P, Verma R, Kumar S, Srivastav SJHA $\mathrm{KK}$ et al. Traditional uses, Phytochemistry and Pharmacological Properties of Moringa oleifera plant: An Overview. Der Pharmacia Lettre 2011;3(2):141-164.

15. Mishra SP, Singh P, Singh S. Processing of Moringa leaves for Human consumption. Bull Env Pharmacol Life Sci 2012;2(1):28-31.

16. Mouminah HHS. Effect of dried Moringa Oleifera leaves on the nutritional and organoleptic characteristics of cookies. Alexandra Science Exchange Journal 2015, 36(4).

17. Odunlade TV, Famuwagun AA, Taiwo KA, Gbadamosi SO. Chemical Composition and Quality Characteristics of Wheat Bread Supplemented with Leafy Vegetable Powders 2017. Hindawi available on online at: https://doi.org/10.1155/2017/9536716. Accessed 27 September 2019.

18. Olushola ATE. The Miracle Tree, Moringa oleifera (Drumstick). In Achieve Vibrant Health with Nature, Keep Hope Alive Series 1, Unijios Consultancy: Limited Press, Jos, Nigeria 2006, 120-136.

19. Prabhu RA, Ranjan AP, Santhalia S. Comparativr analysis of preservstion techniques on Moringa oleifera. Int J Agricultural and Food Science 2011;1(2):12-22.

20. Rebecca HSU, Sharon A, Arbaunsyah, Lucienne. Moringa oleifera: Medicinal and socio - economic uses: International Course on Economic Botany. National
Herbarium Leiden, Netherlands S 2006, 2-6.

21. Rockwood JL, Anderson BG, Casamatta DA. Potential uses of Moringa oleifera and an examination of antibiotic efficacy conferred by Moringa oleifera seed and leaf extracts using crude extraction techniques available to underserved indegeneous population. Int J Phytotherapy Res 2013;3:61-71.

22. Satwase AN, Pandhr GR, Sirsat PG, Wade YR. Studies on Drying Characteristic and Nutritional Composition of Drumstick Leaves by Using Sun, Shadow, Cabinet and Oven Drying Methods 2013. Open access available on online at: http://dx.doi:10.4172/Scientificreports.584. Accessed 27 September 2019.

23. Singh A, Grover K. Post - harvest processing and standardization of value added cereal based traditional recipes for iron security 2014;33(4):267-275.

24. Srinivasamurthy S, Yadav U, Sahay S, Singh A. Int J Food Sci Nutri 2017;2(4):173-178.

25. Tumer T, Rojas SP, Polev A, Raskin I. Direct and indirect antioxidant a ctivity of polyphenol and isothiocyanate- enriched fractions from Moringa oleifera. J Agric Food Chem 2015;63(5):1505-1513.

26. Yameoga CW, Bangaly M, Savadogo A, Nikiema PA, Traore SA. Determination of Chemical Composition and Nutritional Values of Moringa oleifera leaves. Pak J Nutr 2011;10:264-268. 